Article

\title{
Factors Affecting Technology Transfer of Universities in the LINC (Leaders in Industry-University Cooperation) Program of Korea
}

\author{
Seunghoo Jin ${ }^{1}$ and Kangwon Lee ${ }^{2, *}$ \\ Innovation Team, Samsung SDS, Seoul 05510, Korea; jjamesjin@gmail.com \\ 2 Academic Support Team, Korea Institute for Advanced Study, Seoul 02445, Korea \\ * Correspondence: kwlee@kias.re.kr; Tel.: +82-10-5017-3452
}

check for

updates

Citation: Jin, S.; Lee, K. Factors Affecting Technology Transfer of Universities in the LINC (Leaders in Industry-University Cooperation) Program of Korea. Sustainability 2021, 13, 27. https://doi.org/10.3390/ su131810027

Academic Editors: JinHyo Joseph Yun, JungHyun Yoon, Wookjoon Sung, Yuri Sadoi and Valentina Della Corte

Received: 3 August 2021

Accepted: 1 September 2021

Published: 7 September 2021

Publisher's Note: MDPI stays neutral with regard to jurisdictional claims in published maps and institutional affiliations.

Copyright: (C) 2021 by the authors. Licensee MDPI, Basel, Switzerland. This article is an open access article distributed under the terms and conditions of the Creative Commons Attribution (CC BY) license (https:/ / creativecommons.org/licenses/by/ $4.0 /)$.

\begin{abstract}
The purpose of our study was to propose the measures necessary to promote industryacademic cooperation by investigating and analyzing factors affecting its performance Recently, the Korean government increased the budget available for industry-academic cooperation to help nurture industrial talent and promote industry-academic cooperation. In our study, the results of industry-academic cooperation for 48 universities that carried out the 5-year LINC development project from 2012 to 2016 were analyzed via panel analysis to identify any factors affecting the performance. Our analysis revealed that the organizational capabilities of the university-including the number of dedicated professors, the number of projects assigned, and the financial support-had a significant effect on technical commercialization. In addition, we found that the moderating effect of allied companies on the relationship between the organizational capabilities of universities and their technical commercialization was significant. However, the results of our analysis differed depending on university location. Universities in and around the Capital region benefited from their organizational capabilities and cooperation with allied companies. Based on the results of the analysis, we conclude that it is necessary to consider a variety of factors, including efficient support of the industry-academic cooperation budget and practical application of industry-academic cooperation systems.
\end{abstract}

Keywords: industry-university cooperation; technology transfer; performance; panel data analysis

\section{Introduction}

The global economy is becoming increasingly knowledge-based, and changes to the population structure due to low fertility and aging, as well as changes in the technology industry, are affecting society as a whole. In the case of Korea, half of the population lives in the capital area-which comprises only $10 \%$ of the country's area-and most economic activities are also based in the capital area. Therefore, the difficulties faced by the local economy are accelerating. Table 1 shows the data for the imbalance in economic scale between the capital and non-capital regions. The Korean government classifies the country into five economic zones to support and promote various types of financial funds and programs to local governments and universities in these regions. 
Table 1. Economic regions of Korea (2016).

\begin{tabular}{|c|c|c|c|c|c|c|c|c|}
\hline \multirow{2}{*}{ Region } & \multicolumn{2}{|c|}{ Area } & \multicolumn{2}{|c|}{ Population } & \multicolumn{2}{|c|}{ Workforce } & \multicolumn{2}{|c|}{ Regional GDP } \\
\hline & $\left(\mathrm{km}^{2}\right)$ & $\%$ & (* 1000 People) & $\%$ & (* 1000 People) & $\%$ & (1B/KRW) & $\%$ \\
\hline Capital & 11,830 & $12 \%$ & 25,390 & $50 \%$ & 13,194 & $50 \%$ & 813,628 & $50 \%$ \\
\hline Chungcheong & 16,625 & $17 \%$ & 5513 & $11 \%$ & 2807 & $11 \%$ & 209,681 & $13 \%$ \\
\hline Honam & 22,730 & $23 \%$ & 5754 & $11 \%$ & 2890 & $11 \%$ & 166,379 & $10 \%$ \\
\hline Daekyung & 36,741 & $37 \%$ & 6664 & $13 \%$ & 3349 & $13 \%$ & 190,847 & $12 \%$ \\
\hline Dongnam & 12,370 & $12 \%$ & 7946 & $15 \%$ & 3927 & $15 \%$ & 261,422 & $16 \%$ \\
\hline Total & 100,295 & $100 \%$ & 51,269 & $100 \%$ & 26,168 & $100 \%$ & $1,641,957$ & $100 \%$ \\
\hline
\end{tabular}

Source: Statistics Korea (kostat.go.kr, accessed on 30 December 2020) [1]; ${ }^{*}$-people.

The nation's social demands and regional expectations related to university industryacademic cooperation as a way to strengthen national competitiveness are increasing. Therefore, universities will have an impact on their communities by receiving requests and support from them and delivering the results to the local community by performing the three major functions of university educational research [2]. In addition to research and education, which have been emphasized as the major functions of universities thus far, the social relationship between universities and communities will grow as universities actively participate in solving social problems and serving their communities.

Diverse activities are being undertaken to reexamine the social functions of universities and find ways to link them to community revitalization [3]. In Korea, various systems have been prepared, along with financial support projects, to promote industry-academic cooperation. Numerous factions are attempting to expand and distribute various leading models of industry-academic cooperation that address the characteristics of both universities and regional conditions so that they may attract regional development by strengthening the competitiveness of top universities and local enterprises.

LINC (Leaders in Industry-University Cooperation) was a government-funded project to support universities in the five economic regions to develop their research capabilities and global competitiveness from 2012 to 2016.

In addition to the roles the universities play in meeting the needs of these countries and communities, it is also their job to aid in regional development $[3,4]$. To do this, it is important for local universities and industries to cooperatively develop the human resources necessary for local industries. The creation of a model that aids in regional development is also important, because universities and communities are closely related to one another.

However, although the government-allocated budget for university financial support projects for industry-academic cooperation (the LINC project, etc.) is abundant, the fundamental problem of how to measure the relationship between companies and universities remains. There has not been sufficient discussion about whether or not such factors affect industry-academic cooperation performance [4]. In order to respond to the needs of professionals in the business sector, it is necessary for the country to enhance the level of education for future industrial professionals, and to upgrade the professional qualification testing procedures.

This necessitates cooperation between educational institutions and industry [5]. In particular, since this project has been promoted as attracting regional development in response to the demands of the state and the local community, it is essential to establish a rational strategy for industry-academic cooperation activities and any subsequent projects. Against this backdrop, this paper analyzes the effects of various activities (universities' organizational capabilities, dedicated professors for LINC, projects assigned for LINC, and research funding for LINC) related to industry-academic cooperation performance, as well as the effects of institutional, organizational, operational, and industry-academic cooperation education in five economic zones. In the future, the results of this study 
could help to improve industry-academic cooperation policy design and foster further industry-academic cooperation.

\section{Literature Review}

In relation to the term "industry-academic cooperation", the term "mountain" refers to a wide range of private areas such as private companies and non-profit organizations (NPOs). This study represents areas where the cultivation of human resources-such as universities and the creation of new knowledge-is important. The definition of industryacademic cooperation as a concept is the process of developing technology or nurturing human resources; it refers to a phenomenon that coordinates with call functions [6].

From a comprehensive viewpoint, the concept of performance may vary depending on the perspective of the scholars participating in the research. Moon Tae-sun (2005) presented it in the following three categories, in accordance with the concept of performance defined by various scholars [7]:

The first category is the understanding of the achievement goal(s) of an organization from the viewpoint of effectiveness. The second is the understanding of the concept of efficiency and effectiveness, while the third is understanding from the viewpoint of efficiency, effectiveness, responsiveness, and equity. In most of these studies, scholars attempted to measure performance by limiting it to effectiveness- that is, the achievement of goals. However, the concept of effectiveness is limited in terms of rational measurement because of the analytical difficulties regarding effect. In recent years, it has been suggested that the results should be interpreted as a complex and multidimensional concept that includes dimensions of efficiency, goal achievement, service quality, and public level, the last of which also includes the concepts of equity, correspondence, and satisfaction [7].

Kim Bong-moon categorized the achievements of industry-academic cooperation as performance related to people, performance related to technology, and performance related to money [8]. The results of industry-academic cooperation relating to people include education, training, qualifications, support, and employment. The achievements of industry-academic-related cooperation with regard to technology include technical performance according to both explicit and implicit knowledge [8]. The industry-academic cooperation results related to money include start-up companies, negotiations and number of sacraments, advance payments, royalties, and equity rights according to the contract [9]. Siegel et al. analyzed licenses and royalties, knowhow, patents, sponsor research contracts, start-up companies, invention reports, student discharge, and product and economic development as the main output results of industry-academic cooperation [10]. It has also been suggested that the number of patents, license constructions, and license importations be used for relative productivity measurement of the university's technology transfer organization (TLO) [11].

In an overseas study on the impact of industry-academic cooperation on the region, Lendel demonstrated the impact of research centers on the local economy in industryacademic cooperation, presenting them as a role model [12] and suggesting that their impact on the local economy is contingent on the size of the university's investment in R\&D [13]. In addition, the variables related to the performance of industry-academicrelated cooperation can be largely summarized as the number of technology transfers and import fees, the number of joint research tasks and research expenses within industries, and the operating income of joint-use research equipment. The major variables affecting the performance of industry-academic-related cooperation were set as the number of domestic and overseas patent registrations and the capacity of industry-academic cooperation [4]. Smilor, Dietrich, and Gibson classified the results of industry-academic-cooperation into two types: college, and external performance [14].

The Organization for Economic Cooperation (OECD) (1993) referred to the scale of research expenses and the results of orders [15]. In addition, Geisler advocated for categorizing research costs and support for start-ups as industry-academic cooperation [16], while Powers recommended patents, technology transfer performance, and technology 
transfer income [17]. In relation to the ripple effect created by industry-academic cooperation, Baek Cheol-woo and No-min Sun mainly utilized technology transfer, patents, employment creation, and sales increases as industry-academic cooperation performance indices based on the perspective of existing industries (companies) [18]. In terms of universities, eight specific indicators of industry-academic cooperation were used to analyze the quantitative impacts. Because industry-academic cooperation activities and achievements are the results of various activities, there are many factors related to performance. Kim Bong-moon divided the influential factors in industry-academic cooperation performance into competency factors, cooperative policy factors, external environmental factors, total industry-academic cooperation revenue, field practice operation status (number of field students and number of participating companies), joint research results of industry-academic cooperation (number of research tasks and project amounts), and technical transfer results (based on the total number of technical transfers) [8].

As a result of the analysis, it was shown that the competency factors (individuals), cooperative factors, and policy factors had a significant effect on comprehensive performance. At the corporate level, the competency factors of individuals, cooperative factors, policy factors, and external environmental factors all had a significant effect [19]. Based on the data from the LINC project by the Ministry of Education in 2012, Kim Han-ki analyzed each influence factor by classifying the results of industry-academic cooperation as subordinate variables, such as objective performance and subjective performance [20].

According to that analysis, the ratio of the joint research cost to the industry of each professor and field training of the undergraduate students was significantly affected in terms of the employment rate. The subjective assessment of college students' satisfaction was also confirmed as a variable that affected the performance of an industry-academicrelated curriculum. Moon Hyung-jin and Lee Hee-sang compared the performances of the participating universities and non-participating universities by matching the propensity scores based on the evaluation index of the LINC project [21]; they confirmed the significance of the performances by the number of technology transfer cases and the number of teachers. The number of student founders was not confirmed, however [21].

Kim Chang-ho and Lee Seung-chul verified the performance impact factors by utilizing the average value of the evaluation index of the LINC project from 2012 to 2016 [4]. The impact of the budget for industry-academic cooperation on the basic aspects of industry and academia was also demonstrated as being significant. Furthermore, capstone design completion was also confirmed to have a significant impact on students' employment [4].

In overseas countries, industry-academic cooperation is an important policy task, and has a vested interest in the success factors of industry-academic cooperation policies and the measurement of their achievements. Gail et al. suggested empirical factors that resulted in successful partnerships between companies and universities via a case study of 14 universities in the United States [22]. Sadegh et al. presented a framework for industryacademic cooperative performance analysis that covered a variety of industry-academic cooperative performance evaluation studies [23]. Adrian et al. presented an evaluation model of industry-academic cooperation through a case study of 10 universities in Europe. As the model included qualitative, quantitative, long-term, short-term, type/intangible, and direct/indirect effects, the performance evaluation model developed according to the industry-academic cooperation logic model employed in this study was also presented [24]. The input indicators on the presented causal map included human resources (faculty, students, and managers), physical resources (funding, equipment, technology), organizational processes and structures, and final performance indicators.

Yoon Yongjung and Park Daesik determined that the number of patent applications and SCI papers had a positive impact on the technology transfer performance [25], while Moon Hyunggin and Lee Heesang found that the LINC program had a significant effect on technology transfer by comparing 41 universities in the LINC project and 108 universities not in the LINC project [20]. 
Kim Dae-Jung analyzed the policy effectiveness of the LINC project for 42 universities in 5 economic regions (Capital, Chungcheong, Daekyung-Gangwon, Dongnam, and Honam) supported by the LINC project between 2013 and 2016. As a result, it was confirmed that the overall industrial-academic cooperation performance increased rapidly throughout the LINC project, resulting in steady growth of local universities compared to the Capital region, and balanced growth as the gap in industrial-academic cooperation performance among universities was largely resolved [26].

Kong Jae-hyung et al. conducted a survey of university family companies across the country was in order to identify factors that influence the competency of firms and universities in the performance of industry-academic cooperation, and to compare differences by region. It was found that the knowledge and technologies that universities retain and the active participation of companies in the activities of university-academic cooperation were the most important contributors to the corporate achievements in industry-academic cooperation. It was also found that there were significant differences in the capabilities and performance of industry-academic cooperation in the five areas [27].

\section{Materials and Methods}

\subsection{Theoretical Framework and Research Hypothesis}

To determine the supporting effect of the LINC project, 48 universities that were selected to support the LINC project from 2012 to 2016 and promote industry-academic cooperation activities were analyzed (Table 2). Since the project was continuously supported without new entries, data spanning five years (2012-2016) — corresponding to the entire business period-were kept. All of the analysis was completed through a fixed-effects model (FE) and a random-effects model (RE) via least squares linear regression analysis and a panel model. However, the interpretation of pooled OLS was limited because of its estimation convenience in panel data analysis. The study was conducted only after determining whether it was a fixed-effects model or a random-effects model, and the results of the panel model were determined to be reasonable after considering the results of the Hausman specification test. Accordingly, it was possible to conceptually consider significant underlying mechanisms with important variables and elaborate the unobserved variables. Therefore, the panel data analysis utilized in our study suggested optimal models to handle these unobserved missing variables appropriately [4]. Additionally, various analysis techniques that are useful when considering the policy implications can be applied to the panel data model. Using a panel linear regression model with cross-sectional panel data [20], we were able to explore factors that significantly affect the academic performance of universities in the LINC program (Figure 1).

Table 2. Variables.

\begin{tabular}{|c|c|}
\hline Variables & Definition \\
\hline \multicolumn{2}{|c|}{ Dependent Variable: Academic Performance } \\
\hline Indicator for Achievement (TT) & Growth rate of technology transfer \\
\hline \multicolumn{2}{|c|}{ Independent variable: Organizational Capability } \\
\hline Human Resource (HR) & No. of dedicated professors for LINC \\
\hline Projects Assigned (PA) & No. of research projects for LINC \\
\hline Financial Resource (FR) & Research funds for LINC \\
\hline \multicolumn{2}{|c|}{ Moderating Variables: Allied Companies } \\
\hline Allied Cooperation (CO) & No. of allied companies that university cooperates with \\
\hline
\end{tabular}




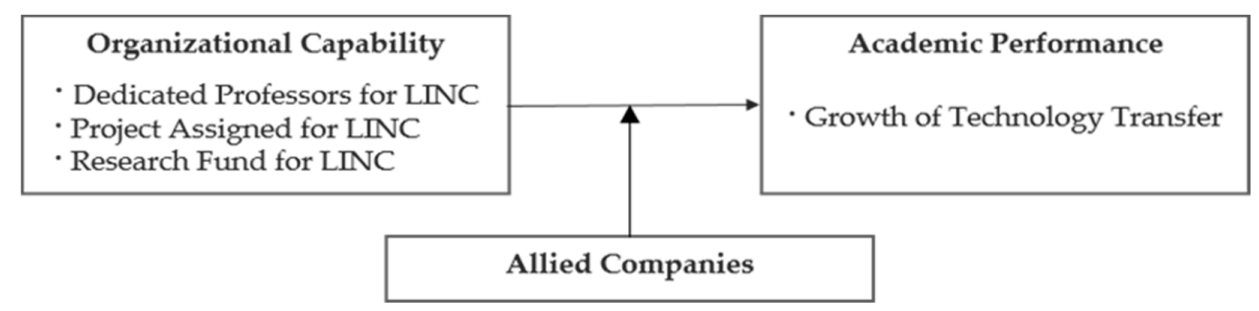

Figure 1. Research framework.

\subsubsection{Hypothesis 1}

The organizational aspect of cooperation between industry and universities will affect the performance positively. Powers et al. determined that technology transfer, import fees, and patents are affected by the human resources of universities [17] and, furthermore, Kim Cheol-hoe stated that the number of expert personnel in charge of technology transfer has a positive impact on the number of technology transfers [4].

Kim stated that the education level of employees of the university affects technology transfer and commercialization [28]. Og Joo-Young explained that the size of the dedicated organization affects the number of technology transfers [29]. Therefore, it can be assumed that the organizational capabilities of universities can have a positive effect on a university's performance by creating new technology and transferring it to companies in order to enhance their competitiveness in a hypercompetitive business environment. Hypothesis 1 is proposed as follows:

Hypothesis 1 (H1). Organizational capabilities, dedicated professors for LINC, projects assigned for LINC, and research funding for LINC will have a beneficial effect on a university's technology transfer.

Hypothesis 1a (H1a). Dedicated professors for LINC will have a beneficial effect on technology transfer.

Hypothesis 1b (H1b). Projects assigned for LINC will have a beneficial effect on technology transfer.

Hypothesis 1c (H1c). Research funding for LINC will have a beneficial effect on technology transfer.

\subsubsection{Hypothesis 2}

Family companies were found to have achieved improved recognition and satisfaction through participation in industry-academic cooperation programs. The efficient operation of industry-academic cooperation programs is essential to increasing the efficiency of industry.

Youngsoo Ryu explained that cooperating with allied companies had a significant effect on the performance of universities [30], while Lee Sang-cheon participated in the industry-academic cooperation center university project conducted by K University in 2009 and 2012 [31], and studied the satisfaction of family companies with the industry-academic cooperation program [32]. Lee Sang-mi verified the effectiveness of the LINC program by analyzing the increase in the number of allied companies cooperating [33]. Therefore, it was assumed in this study that allied companies play an important role in the relationship between the organizational capabilities and the academic performance of universities, and the following Hypotheses 2 is presented:

Hypothesis 2 (H2). Cooperation with allied companies will have a beneficial moderating effect on the relationship between organizational capability and technology transfer.

Hypothesis 2a (H2a). Cooperation with allied companies will have a beneficial moderating effect on the relationship between dedicated professors for LINC and technology transfer. 
Hypothesis $\mathbf{2} \mathbf{b} \mathbf{( H 2 b )}$. Cooperation with allied companies will have a beneficial moderating effect on the relationship between dedicated projects for LINC and technology transfer.

Hypothesis 2c (H2c). Cooperation with allied companies will have a beneficial moderating effect on the relationship between research funding for LINC and technology transfer.

\subsection{Data Collection and Processing}

The research was centered on quantifiable data, and the data extraction method was based on the results of industry-academic cooperation activities from universities, and evaluated by the Korea Research Foundation. Based on the core performance index of the LINC project, the data used in this research were submitted annually by the university, and only data verified through the expert evaluation (annual or stage evaluation) of the Korea Research Foundation were utilized. If there was an objection to the results of the expert review, the process was finalized through a separate call, so the possibility of performance and data error was reduced to a minimum. The 48 universities comprised 14 with technological innovation and 37 with on-site contacts. The basic statistics used for the independent and dependent variables of this study are as follows (Table 3):

Table 3. Descriptive statistic results of main variables.

\begin{tabular}{|c|c|c|c|c|c|c|c|c|c|c|}
\hline \multirow{2}{*}{ Characteristic } & \multicolumn{2}{|c|}{$\begin{array}{l}\text { Capital } \\
\text { Region }\end{array}$} & \multicolumn{2}{|c|}{$\begin{array}{c}\text { Chungcheong } \\
\text { Region }\end{array}$} & \multicolumn{2}{|c|}{$\begin{array}{c}\text { Daekyung } \\
\text { Region }\end{array}$} & \multicolumn{2}{|c|}{$\begin{array}{c}\text { Dongnam } \\
\text { Region }\end{array}$} & \multicolumn{2}{|c|}{$\begin{array}{l}\text { Honam } \\
\text { Region }\end{array}$} \\
\hline & Average & $\begin{array}{l}\text { Standard } \\
\text { Deviation }\end{array}$ & Average & $\begin{array}{l}\text { Standard } \\
\text { Deviation }\end{array}$ & Average & $\begin{array}{l}\text { Standard } \\
\text { Deviation }\end{array}$ & Average & $\begin{array}{l}\text { Standard } \\
\text { Deviation }\end{array}$ & Average & $\begin{array}{c}\text { Standard } \\
\text { Deviation }\end{array}$ \\
\hline $\begin{array}{c}\text { Growth of } \\
\text { Technology Transfer } \\
\text { (TT) }\end{array}$ & 7.746 & 0.879 & 6.732 & 1.136 & 5.900 & 1.290 & 6.604 & 0.963 & 6.631 & 0.924 \\
\hline $\begin{array}{c}\text { Dedicated } \\
\text { Professors (HR) }\end{array}$ & 3.073 & 0.359 & 3.219 & 0.545 & 2.795 & 0.700 & 3.168 & 0.405 & 2.835 & 0.400 \\
\hline $\begin{array}{l}\text { Projects } \\
\text { Assigned } \\
\quad(\mathrm{PA})\end{array}$ & 0.674 & 0.463 & 0.606 & 0.409 & 0.324 & 0.228 & 0.427 & 0.235 & 0.286 & 0.169 \\
\hline $\begin{array}{l}\text { Financial } \\
\text { Resource } \\
\quad \text { (FR) }\end{array}$ & 9.837 & 1.094 & 9.469 & 0.859 & 8.834 & 0.980 & 9.135 & 1.099 & 8.876 & 1.059 \\
\hline $\begin{array}{c}\text { Allied } \\
\text { Companies } \\
(\mathrm{CO})\end{array}$ & 7.016 & 0.705 & 6.656 & 0.472 & 6.058 & 0.535 & 6.303 & 0.495 & 6.013 & 0.455 \\
\hline Observation & & 35 & & 55 & & 55 & & 55 & & 55 \\
\hline
\end{tabular}

In our study, a panel analysis model was used to independently measure the contributions of each variable based on the relationships between several independent variables measuring a variety of industry-academic cooperation activities and performances. The units of each variable were standardized prior to analysis with various scores, amounts, and ratios, and reviewed using the Stata 14.2 statistical program for suitability for panel analysis. The dependent variables required to perform panel analysis utilized variables related to the academic performance achieved through industry-academic cooperation, while the independent variables for each dependent variable made use of various organizational aspects as variables. The capacity of allied companies was used as a variable to analyze the moderating effect of the relationship between the organizational capabilities of universities and their technology transfer performances (Table 4). 
Table 4. Correlation summary of the main variables.

\begin{tabular}{|c|c|c|c|c|c|c|}
\hline Capital Region & TT & HR & PA & FR & $\mathrm{CO}$ & VIF \\
\hline $\mathrm{TT}$ & 1.000 & & & & & \\
\hline HR & $0.130 * * *$ & 1.000 & & & & 7.22 \\
\hline PA & $0.196^{* *}$ & $0.155^{*}$ & 1.000 & & & 4.82 \\
\hline FR & 0.368 * & $0.030^{* *}$ & $0.882^{* *}$ & 1.000 & & 4.55 \\
\hline $\mathrm{CO}$ & $0.199 * *$ & $0.355^{* *}$ & $0.853^{* * *}$ & $0.751 *$ & 1.000 & 1.34 \\
\hline $\begin{array}{c}\text { Chungcheong } \\
\text { Region }\end{array}$ & $\mathrm{TT}$ & HR & PA & FR & $\mathrm{CO}$ & VIF \\
\hline $\mathrm{TT}$ & 1.000 & & & & & \\
\hline HR & $0.478 * *$ & 1.000 & & & & 2.42 \\
\hline PA & $0.556^{* *}$ & $0.053^{*}$ & 1.000 & & & 2.23 \\
\hline FR & $0.658 *$ & $0.011 *$ & $0.758^{* * *}$ & 1.000 & & 1.23 \\
\hline $\mathrm{CO}$ & $-0.097^{* *}$ & $0.295^{* *}$ & $-0.358^{* *}$ & $-0.079 *$ & 1.000 & 1.03 \\
\hline Daekyung Region & $\mathrm{TT}$ & HR & PA & FR & $\mathrm{CO}$ & VIF \\
\hline $\mathrm{TT}$ & 1 & & & & & \\
\hline HR & 0.074 * & 1.000 & & & & 2.27 \\
\hline PA & $0.414^{* *}$ & $-0.293 *$ & 1 & & & 1.75 \\
\hline FR & $0.481 * *$ & $-0.233 *$ & $0.566^{* * *}$ & 1.000 & & 1.55 \\
\hline $\mathrm{CO}$ & $0.136^{*}$ & $0.097 *$ & $-0.045^{*}$ & $-0.513 *$ & 1 & 1.10 \\
\hline Dongnam Region & $\mathrm{TT}$ & HR & PA & FR & $\mathrm{CO}$ & VIF \\
\hline $\mathrm{TT}$ & 1.000 & & & & & \\
\hline HR & $0.524^{* *}$ & 1.000 & & & & 2.98 \\
\hline PA & $0.232 * *$ & $-0.100 *$ & 1.000 & & & 2.97 \\
\hline FR & $0.503^{* * *}$ & $-0.016^{* *}$ & $0.810^{* *}$ & 1.000 & & 1.70 \\
\hline $\mathrm{CO}$ & $0.305^{* *}$ & $0.633^{* * *}$ & -0.070 * & $-0.040 *$ & 1.000 & 1.67 \\
\hline Honam Region & $\mathrm{TT}$ & HR & PA & FR & $\mathrm{CO}$ & VIF \\
\hline $\mathrm{TT}$ & 1.000 & & & & & \\
\hline HR & $0.367^{* *}$ & 1.000 & & & & 3.61 \\
\hline PA & 0.638 * & $-0.267^{* *}$ & 1.000 & & & 3.28 \\
\hline FR & $0.746^{* *}$ & $-0.297^{* *}$ & $0.620^{* * *}$ & 1.000 & & 2.58 \\
\hline $\mathrm{CO}$ & $0.071 *$ & 0.566 * & 0.378 * & $-0.069 *$ & 1.000 & 2.08 \\
\hline
\end{tabular}

***,**, and * represent significance at the levels of 1,5 , and $10 \%$, respectively.

\section{Result}

Our study was conducted with the most widely used fixed-effects and random-effects models in panel analysis. The fixed-effects and random-effects models for panel analysis can vary depending on which model is selected, so we used the Hausman test to select the appropriate models - either fixed-effects model or random-effects model-based on the assumption. Based on the results of the Hausman test, a fixed-effects model was applied to analyze the Capital, Daekyung, and Honam regions, and a random-effects model was used for analysis of the Chungcheong and Dongnam regions. The results are shown in Table 5. 
Table 5. Panel regression estimation results.

\begin{tabular}{|c|c|c|c|c|c|}
\hline \multirow{2}{*}{ Characteristic } & \multicolumn{5}{|c|}{ Technology Transfer (TT) } \\
\hline & Capital & Chungcheong & Daekyung & Dongnam & Honam \\
\hline $\begin{array}{l}\text { Dedicated } \\
\text { Professors } \\
\quad(\mathrm{HR})\end{array}$ & $\begin{array}{c}0.458^{* *} \\
(1.203)\end{array}$ & $\begin{array}{l}2.090 \text { * } \\
(1.242)\end{array}$ & $\begin{array}{c}1.797^{* * *} \\
(0.523)\end{array}$ & $\begin{array}{c}1.747 \\
(1.162)\end{array}$ & $\begin{array}{c}-0.462 \\
(0.537)\end{array}$ \\
\hline $\begin{array}{l}\text { Projects } \\
\text { Assigned } \\
\text { (PA) }\end{array}$ & $\begin{array}{c}24.05^{* * *} \\
(3.792)\end{array}$ & $\begin{array}{l}6.052 * \\
(3.546)\end{array}$ & $\begin{array}{l}-2.202 \\
(3.190)\end{array}$ & $\begin{array}{c}3.558 \\
(4.930)\end{array}$ & $\begin{array}{c}1.425 \\
(1.442)\end{array}$ \\
\hline $\begin{array}{l}\text { Research } \\
\text { Funding } \\
\text { (FR) }\end{array}$ & $\begin{array}{c}4.658^{* * *} \\
(1.279)\end{array}$ & $\begin{array}{c}5.216^{* * *} \\
(1.311)\end{array}$ & $\begin{array}{c}2.554^{* *} \\
(1.070)\end{array}$ & $\begin{array}{l}2.583^{* *} \\
(1.086)\end{array}$ & $\begin{array}{c}0.554 \\
(0.406)\end{array}$ \\
\hline $\begin{array}{c}\text { Allied } \\
\text { Companies } \\
(\mathrm{CO})\end{array}$ & $\begin{array}{l}4.468^{* *} \\
(1.895)\end{array}$ & $\begin{array}{c}6.6011^{* * *} \\
(1.752)\end{array}$ & $\begin{array}{l}3.070 * * \\
(0.084)\end{array}$ & $\begin{array}{c}4.222 * * * \\
(1.525)\end{array}$ & $\begin{array}{c}1.665^{* * *} \\
(0.600)\end{array}$ \\
\hline $\mathrm{HR}^{*} \mathrm{CO}$ & $\begin{array}{l}1.341^{* *} \\
(0.958)\end{array}$ & $\begin{array}{c}0.168 \\
(0.180)\end{array}$ & $\begin{array}{c}0.307^{* * *} \\
(0.084)\end{array}$ & $\begin{array}{c}0.251 \\
(0.158)\end{array}$ & $\begin{array}{c}0.090 \\
(0.087)\end{array}$ \\
\hline $\mathrm{PA}^{*} \mathrm{CO}$ & $\begin{array}{c}3.357^{* * *} \\
(0.568)\end{array}$ & $\begin{array}{l}1.007 \text { * } \\
(0.494)\end{array}$ & $\begin{array}{c}0.133 \\
(0.450)\end{array}$ & $\begin{array}{c}0.316 \\
(0.764)\end{array}$ & $\begin{array}{c}0.289 \\
(0.226)\end{array}$ \\
\hline $\mathrm{FR}^{*} \mathrm{CO}$ & $\begin{array}{c}0.559^{* * *} \\
(0.177)\end{array}$ & $\begin{array}{c}0.715^{* * *} \\
(0.187)\end{array}$ & $\begin{array}{c}0.589 * * * \\
(0.155)\end{array}$ & $\begin{array}{c}0.526^{* * *} \\
(0.180)\end{array}$ & $\begin{array}{c}0.170 * * * \\
(0.057)\end{array}$ \\
\hline Cons & $\begin{array}{c}31.16 \\
(11.43)\end{array}$ & $\begin{array}{l}45.00 * * * \\
(12.053)\end{array}$ & $\begin{array}{c}20.316^{* *} \\
(9.606)\end{array}$ & $\begin{array}{c}27.666^{* * *} \\
(9.097)\end{array}$ & $\begin{array}{c}2.500 \\
(4.184)\end{array}$ \\
\hline $\mathrm{F}$ & $84.83^{* * *}$ & $191.34^{* * *}$ & $65.20^{* * *}$ & $165.65^{* * *}$ & $61.28^{* * *}$ \\
\hline$R^{2}$ & 0.149 & 0.593 & 0.199 & 0.328 & 0.541 \\
\hline $\begin{array}{c}\text { Hausman } \\
\text { Test }\end{array}$ & 0.000 & 0.449 & 0.050 & 0.462 & 0.025 \\
\hline $\mathrm{N}$ & 35 & 55 & 55 & 55 & 55 \\
\hline
\end{tabular}

\subsection{Capital Region}

According to the test results of Hypotheses 1 and 2 for the Capital region, the hypothesis analyzed with the fixed-effects model was found to be significant, as the null hypothesis was rejected based on the regression equation $\left(R^{2}: 14.9 \%, p\right.$-value $\left.<0.00\right)$, indicating that the organizational capabilities of the university had a positive $(+)$ effect on the technology transfer performance of the university with regard to the dedicated professors for LINC $(ß=0.458, p$-value $<0.05)$, projects assigned for LINC $(\beta=24.05, p$-value $<0.01)$, research funds for LINC $(\beta=4.658, p$-value $<0.01)$, and allied companies $(\beta=4.468, p$-value $<0.05)$. This implies that the organizational capabilities of the university contributed to increasing the performance of the university.

Hypothesis 2 analyzed the moderating effect of cooperating with allied companies.

The analysis of the moderating effect of allied companies on the relationship between dedicated professors and the technology transfer performance $(\beta=1.341, p$-value $<0.05)$, projects assigned and the performance $(\beta=3.357, p$-value $<0.01)$, and research funding and the performance $(~(\beta=0.559, p$-value $<c 0.01)$ found a statistically significant effect on technology transfer in all cases. Similarly to Hypothesis 1, this also implies that the moderating effect of allied companies contributed to enhancing the technology transfer.

\subsection{Chungcheong Region}

According to the test results of Hypotheses 1 and 2 for the Chungcheong region, the hypothesis analyzed with the random-effects model was found to be significant 
$\left(\mathrm{R}^{2}: 59.3 \%\right.$, $p$-value $\left.<0.00\right)$, indicating that the organizational capabilities of the university had a positive $(+)$ effect on the technology transfer performance of the university in the Chungcheong region in terms of the dedicated professors for LINC ( $B=2.090$, $p$-value $<0.1)$, projects assigned for LINC $(\beta=6.052, p$-value $<0.1)$, research funds for LINC $(B=5.216, p$-value $<0.01)$, and allied companies $(B=6.601, p$-value $<0.01)$. The results of Hypothesis 2 were the same as the results for the Capital region, except that the interaction terms of dedicated professors and allied companies did not have a significant effect on the technology transfer performance of the universities.

\subsection{Daekyung-Gangwon Region}

The fixed-effects model $\left(R^{2}: 19.9 \%, p\right.$-value $\left.<0.00\right)$ was used to analyze the effects of dedicated professors for LINC (HR), projects assigned for LINC (PA), research funds for LINC (FR), the number of allied companies (CO), and the interaction terms of the variables $\left(\mathrm{HR}^{*} \mathrm{CO}, \mathrm{PA}^{*} \mathrm{CO}, \mathrm{FR}^{*} \mathrm{CO}\right)$ used for analyzing moderating effects on the technology transfer performance of universities in Daekyung-Gangwon region. According to the results, dedicated professors for LINC, research funds for LINC, allied companies, and the interaction terms $\mathrm{HR}^{*} \mathrm{CO}$ and $\mathrm{FR}^{*} \mathrm{CO}$ had significant effects on technology transfer; however, projects assigned for LINC and the interaction term $\mathrm{PA}^{*} \mathrm{CO}$ did not have significant effects.

\subsection{Dongnam Region}

The random-effects model $\left(R^{2}: 32.8 \%, p\right.$-value $\left.<0.00\right)$ was used to analyze the effects of dedicated professors for LINC (HR), projects assigned for LINC (PA), research funds for LINC (FR), the number of allied companies (CO), and the interaction terms of the variables $\left(\mathrm{HR}^{*} \mathrm{CO}, \mathrm{PA}^{*} \mathrm{CO}, \mathrm{FR}^{*} \mathrm{CO}\right)$ used for analyzing moderating effects on the technology transfer performance of universities in Dongnam region. The analysis revealed that research funds for LINC, allied companies, and the interaction term $\mathrm{FR}^{*} \mathrm{CO}$ had significant effects on the technology transfer performance; however, the other variables did not have a significant effect on technology transfer.

\subsection{Honam Region}

The fixed-effects model (R2: $54.1 \%, p$-value $<0.00)$ was used to analyze the effects of dedicated professors for LINC (HR), projects assigned for LINC (PA), research funds for LINC (FR), the number of allied companies (CO), and the interaction terms of the variables $\left(\mathrm{HR}^{*} \mathrm{CO}, \mathrm{PA}^{*} \mathrm{CO}, \mathrm{FR}^{*} \mathrm{CO}\right)$ used for analyzing moderating effects on the technology transfer performance of universities in Honam region. Only allied companies and the interaction term $\mathrm{FR}^{*} \mathrm{CO}$ had significant effects on technology transfer; however, no other variables were found to be statistically significant factors affecting technology commercialization performance.

\section{Discussion}

The results of our study indicate that organizational factors of universities and cooperation with allied companies contribute significantly to enhancing sustainable academia performance for the universities in the LINC program. Organizational factors, dedicated professors, dedicated projects, and research funding have significant effects on the academic performance of universities, and cooperation with allied companies exerts a moderating effect on the relationship between organizational factors and the academic performance of universities. These results are consistent with previous studies showing that organizational factors and cooperation with allied companies have positive effects on academic performance $[26,27]$. As discussed in the literature, the capabilities of universities to retain and actively cooperate with companies contribute to the academic achievements in industryacademic cooperation, and it has been mentioned that there are significant differences in the effects on performances in the five regions [27]. The LINC program played an important role in universities' academic development, as it provided significant resources to support universities to enhance their capabilities for the rapid competitive environment [26]. 
We made use of fixed-effects and random-effects panel data models to test the relationship between organizational capabilities and technology transfer performance, which confirmed Hypothesis 1, while the moderating effect of cooperation with allied companies confirmed Hypothesis 2. The positive and significant relationship between organizational capabilities and technology transfer performance corroborated Hypothesis 1 of our work, indicating that the organizational capabilities of universities are beneficial to enhancing the universities' technology transfer performance. The positive and significant moderating effect of the cooperation with allied companies on the relationship between organizational capabilities and technology transfer performance showed that having better relationships with allied companies in the region is beneficial to improving the academic performance of the universities. However, it seems that the results varied depending on the regions in which the universities were located. The results of this analysis can be summarized as follows:

\subsection{Organizational Capabilities: Conclusion and Suggestions}

First, the results in Table 6 show that, for the universities in the Capital, Chungcheong, and Daekyung regions, dedicated professors for LINC had a significant impact on technology transfer, but this was not the case for the universities in the Dongnam and Honam regions. This is mainly because there were differences in the research levels of professors in each region, as excellent professors wanted to work mainly at universities located in the Capital region or nearby. According to the World QS ranking evaluation that assessed university infrastructure and organizational competitiveness, the number of professors, research development, etc., the universities in the Capital region and universities specializing in science and technology in the Chungcheong region received higher ratings compared to those in other regions.

Table 6. Hypothesis results.

\begin{tabular}{|c|c|c|c|c|c|c|}
\hline & Hypothesis & Capital & Chungcheong & Daekyung & Dongnam & Honam \\
\hline \multicolumn{7}{|c|}{ H1: Organizational capability will have a beneficial effect on universities' technology transfer. } \\
\hline $\mathrm{H} 1 \mathrm{a}$ & $\begin{array}{l}\text { Dedicated professors for LINC will have a beneficial effect } \\
\text { on universities' technology transfer. }\end{array}$ & $\mathrm{O}$ & $\mathrm{O}$ & $\mathrm{O}$ & $x$ & $x$ \\
\hline $\mathrm{H} 1 \mathrm{~b}$ & $\begin{array}{l}\text { Dedicated projects for LINC will have a positive effect on } \\
\text { universities' technology transfer. }\end{array}$ & $\mathrm{O}$ & $\mathrm{O}$ & $x$ & $x$ & $x$ \\
\hline $\mathrm{H} 1 \mathrm{c}$ & $\begin{array}{l}\text { Research funding for LINC will have a beneficial effect on } \\
\text { universities' technology transfer. }\end{array}$ & $\mathrm{O}$ & $\mathrm{O}$ & $\mathrm{O}$ & $\mathrm{O}$ & $x$ \\
\hline \multicolumn{7}{|c|}{$\begin{array}{l}\text { H2: Cooperation with allied companies will have a beneficial moderating effect on the relationship between organizational } \\
\text { capability and technology transfer. }\end{array}$} \\
\hline $\mathrm{H} 2 \mathrm{a}$ & $\begin{array}{l}\text { Cooperation with allied companies will have a beneficial } \\
\text { moderating effect on the relationship between dedicated } \\
\text { professors for LINC and technology transfer. }\end{array}$ & $\mathrm{O}$ & $x$ & $\mathrm{O}$ & $x$ & $x$ \\
\hline $\mathrm{H} 2 \mathrm{~b}$ & $\begin{array}{l}\text { Cooperation with allied companies will have a beneficial } \\
\text { moderating effect on the relationship between dedicated } \\
\text { projects for LINC and technology transfer. }\end{array}$ & $\mathrm{O}$ & $\mathrm{O}$ & $x$ & $x$ & $x$ \\
\hline $\mathrm{H} 2 \mathrm{c}$ & $\begin{array}{l}\text { Cooperation with allied companies will have a beneficial } \\
\text { moderating effect on the relationship between research } \\
\text { funds for LINC and technology transfer. }\end{array}$ & $\mathrm{O}$ & $\mathrm{O}$ & $\mathrm{O}$ & $\mathrm{O}$ & $x$ \\
\hline
\end{tabular}

Note: $\mathrm{O}-$ Hypothesis is accepted, $\mathrm{X}-$ Hypothesis is not accepted.

Second, dedicated projects for LINC more significantly enhanced technology transfer performance in the Capital and Chungcheong regions. However, there was no significant effect for universities in the Daekyung, Dongnam, and Honam regions. This is mainly because the Capital region, with its superior local infrastructure, and the Chungcheong region, where many government research institutes are located, were able to perform more 
quantitative and qualitative projects than the Daekyung, Dongnam, and Honam regions, with their relatively poor local infrastructures.

Third, research funding for LINC had a significant impact on technology transfer performance in the Capital, Chungcheong, Daekyung, and Dongnam regions, but not in the Honam region.

\subsection{Cooperation with Allied Companies and Suggestions}

The results of Table 6 show that the mediating effect of cooperation with allied companies on organizational capabilities and technology transfer performance was most obvious in the Capital and Chungcheong regions, indicating that the academic performance of universities can be enhanced by cooperating with allied companies in regions where universities are situated. This is mainly because, in Korea's economic structure, most large corporations are located in the Capital region, and many public institutions are moving to areas outside the Capital region as a result of the government's policy of moving public institutions that are located near the Capital region or Chungcheong region.

The allied companies in the Daekyung, Dongnam, and Honam regions are mostly large corporations' production factories or small and medium-sized manufacturing companies, so conducting research on new technology with universities is not their primary purpose. For this reason, universities in the Capital and Chungcheong regions show high results compared to other regions in terms of creating new technology outcomes by cooperating with local allied companies.

Based on this analysis, the following suggestions are proposed for improving the technology transfer performance of universities: First, universities in areas where the local infrastructure for research and cooperation is not sufficient should consider ways to optimize their capabilities and enhance their organizational capabilities through active exchanges with other regions. Second, for universities in areas where local infrastructure is scarce, central and local government should consider changing the support policy to improve basic education infrastructure and the compensation for professors, so that those with excellent research capabilities can unite to conduct better research. Third, it is necessary to establish a new policy that can support universities in developing a regional specialization rather than applying one policy to all universities in order to resolve the regional university competency imbalance.

\section{Conclusions}

This research is meaningful in that it examines the changes in industry-academic cooperation in the five economic zones in Korea, and seeks to define its achievements, limitations, and alternatives centered on the government's support policies for industryacademic cooperation. Our analysis was based on the results of a five-year project to promote industry-academic cooperation, as the representative government financial support project related to industry-academic cooperation. Based on the results of this research, the organizational capabilities of universities can improve their academic and technology transfer performance. Furthermore, cooperation with allied companies in their regions will enhance the effects of the universities' organizational capabilities on their academic performance.

First, the fact that the LINC project from 2012 to 2016 contributed significantly to universities' industry-academic cooperation performance was verified via the basic statistics. In the case of the effects of organizational capabilities on the performance of universities, it was found that revision of the regulations was promoted to establish an inducement system to incentivize active engagement in industry-academic cooperation activities by universities, enhancing their organizational capabilities. As a result, it was also deemed important to secure the organizational structure of the universities. Second, systematic support and management related to cooperation with family companies related to LINC businesses is needed. As shown in this study, the most significant item impacting industryacademic cooperation performance was the number of family companies involved, which 
had a positive effect on the number of technical commercialization results. However, in order for this to be effective, it is necessary to activate a family company system that can secure the interest and participation of companies, as this is the important subject of industry-academic cooperation. It is crucial to develop and apply programs that are mutually beneficial for both universities and companies by strengthening cooperation programs based on corporate demand. It is necessary for universities to enhance capabilities related to industry-academic-related connections by improving the research infrastructure for the development of new technology in order to hire better research professors, create new segmented projects, and secure sufficient funding for research. Educational programs that can be linked to technology transfer to enterprises through securing intellectual property rights, or to start-ups using the relevant technology, are also imperative.

Third, there were significant differences in the capabilities and achievements in industry-academic cooperation between the five economic regions (Capital, Chungcheong, Daekyung-Gangwon, Dongnam, and Honam); thus, it is necessary to establish a specialized industry-academic cooperation policy, and promote projects for each region in order to enhance the effectiveness of industry-academic cooperation.

The results of our analysis show that the LINC program, conducted from 2012 to 2016, contributed significantly to universities' academic performance. Professors actively participate in industry-academic cooperation via human resource support systems, and differential financial support led universities to actively participate. Early industry-academic cooperation began with only educational support for students, but since then it has developed significantly, with cooperation such as technology transfer and patent creation based on companies' demand. When implementing an industry-academic cooperation program such as LINS at a global scale, various factors such as human resource support policy, financial support, and evaluation system should be considered.

The main limitation of this research was that it was quantitative and performanceoriented research utilizing both industry-academic cooperation activities and achievements, and the fundamental limitations of empirical analysis in terms of its methodology cannot be denied. Various approaches are needed in order to increase its real explanatory ability, including evaluation of the number of possible causes between various influencing factors, and the influence of variables excluded from the analysis of this study. In the future, it will be necessary to combine qualitative research efforts that can be classified under industry-academic cooperation activities and achievements. In addition, it is necessary to conduct qualitative studies that compare and analyze cases of excellent industry-academic cooperation activities and achievements by region.

In order to measure the practical policy effectiveness of the LINC project, it is necessary to compare the business variables before and after the implementation of LINC, and to compare performance between LINC beneficiary universities and non-LINC universities. For the comprehensive analysis to determine the performance and impact factors of industry-academic cooperation in the future, additional research should be conducted by expanding analysis targets and supplementing methodologies.

Additionally, there are many differences in performance between universities by region, and most domestic universities do not produce technology transfer results, so research and consideration of overall university technology transfer activities will be needed.

Author Contributions: Conceptualization, S.J. and K.L.; methodology, S.J. and K.L.; software, S.J.; validation, S.J. and K.L.; formal analysis, S.J.; investigation, S.J.; resources, S.J.; data curation, S.J. and K.L.; writing —original draft preparation, S.J.; writing—review and editing S.J. and K.L.; visualization, S.J.; supervision, K.L. All authors have read and agreed to the published version of the manuscript.

Funding: This research received no external funding.

Institutional Review Board Statement: Not applicable.

Informed Consent Statement: Not applicable.

Data Availability Statement: Data sharing not applicable. 
Conflicts of Interest: The authors declare no conflict of interest.

\section{References}

1. Statistics Korea. Available online: www.kostat.go.kr (accessed on 30 December 2020).

2. Dong, F.; Xie, Y.; Cao, L. Board power hierarchy, corporate mission, and green performance. Sustainability 2019, $11,4826$. [CrossRef]

3. Kim, C.Y. A Study on Revitalization of Local Communities Through Collaboration with University-Focusing on Case Studies of Collaboration Planning Program between Local Universities and Communities in Japan. J. Urban Des. Inst. Korea Urban Des. 2013, $14,65-78$.

4. Kim, C.H.; Yi, S.C. A Study on the performance of industry-university co-operations program: Centered around the performance of LINC (Leaders in Industry-university Cooperation) program. GRI Res. Bull. 2016, 18, 77-102.

5. Shum, K.; Kodama, F.; Shibata, T. Towards a Longitudinal Outlook on Industry Transition Management. J. Open Innov. Technol. Mark. Complex. 2020, 6, 79. [CrossRef]

6. Yun, J.J.; Zhao, X. Business Model Innovation through a Rectangular Compass: From the Perspective of Open Innovation with Mechanism Design. J. Open Innov. Technol. Mark. Complex. 2020, 6, 131. [CrossRef]

7. Lee, Y.J.; Shin, K.; Kim, E. The influence of a firm's capability and dyadic relationship of the knowledge base on ambidextrous innovation in biopharmaceutical M\&As. Sustainability 2019, 11, 4920.

8. Kim, C.Y.; Lim, M.S.; Yoo, J.W. Ambidexterity in external knowledge search strategies and innovation, performance: Mediating role of balanced innovation and moderating role of absorptive capacity. Sustainability 2019, 11, 5111. [CrossRef]

9. Cha, N.; Hwang, J.; Kim, E. How to Improve Performance and Diversity of Government-Funded Research Institute Ecosystem? Focus on Result Sharing and Feedback Policy. J. Open Innov. Technol. Mark. Complex. 2019, 5, 66. [CrossRef]

10. Yun, J.J.; Jeong, E.; Lee, Y.K.; Kim, K.H. The effect of open innovation on technology value and technology transfer: A comparative analysis of the automotive, robotics, and aviation industries of Korea. Sustainability 2018, 10, 2459. [CrossRef]

11. Lester, R. Universities, Innovation, and the Competitiveness of Local Economies: Summary Report from the Local Innovation Project (MIT-IPC-05-010); MIT: Cambridge, MA, USA, 2005.

12. Lendel, I. The impact of research universities on regional economies: The concept of university products. Econ. Dev. Q. 2010, 24, 210-230. [CrossRef]

13. Smilor, R.W.; Dietrich, G.B.; Gibson, D.V. The entrepreneurial university: The role of higher education in the United States in technology commercialization and economic development. Int. Soc. Sci. J. 1993, 45, 1-11.

14. Chen, J.; Han, L.; Qu, G. Citizen Innovation: Exploring the Responsibility Governance and Cooperative Mode of a "PostSchumpeter" Paradigm. J. Open Innov. Technol. Mark. Complex. 2020, 6, 172. [CrossRef]

15. Geisler, E. Organizational and Managerial Dimension of Industry-University Government R\&D Cooperation: A Global Perspective. The Special Academy of Management Conference of the Organizational Dimensions of Global Change: No Limits to Cooperation. Presentation conducted at Case Western Reserve University, Cleveland, OH, USA, 3-6 May 1995.

16. Powers, J.B. Commercializing Academic Research; Resource Effects on Performance of University Technology Transfer. J. High. Educ. 2003, 74, 26-50. [CrossRef]

17. Baek, C.B.; Lee, K.J.; Noh, M.S. Spillover Effect of Partnership between Industry and University in Local Universities. Korean Local Adm. Rev. 2016, 13, 167-185.

18. Kim, H.K. Study on Determinants of LINC Program Performance. Ph.D. Thesis, Hannam University, Daejeon, Korea, 2015.

19. Kim, J.H.; Eom, S.J. The managerial dimension of open data success: Focusing on the open data initiatives in Korean local governments. Sustainability 2019, 11, 6758. [CrossRef]

20. Moon, H.J.; Lee, H.S. The Effects of Government Financial Support on the Performance of Industry-University Cooperation. J. Technol. Innov. 2016, 24, 29-52. [CrossRef]

21. Gail, E.; Lori, V.; Michael, K.; Richard, L.H.; Haydn, B. Making Industry-University Partnerships Work: Lessons from Successful Collaborations; Science I Business Innovation Board AISBL: Brussels, Belgium, 2012.

22. Adrian, H.; Markus, P.; John, G.; Louise, K. Measuring the Impact of University Business Cooperation; European Union: Luxembourg, 2014.

23. Pauuwe, J.; Richardson, R. Introduction special issue on HRM and performance. Int. J. Hum. Resour. Manag. 1997, 8, $257-262$.

24. Heneman, R.L. Merit Pay: Linking Pay Increases to Performance Ratings; Addison-Wesley Publishing Company: Boston, MA, USA, 1992.

25. Yoon, Y.J.; Park, D.S. The Impact of the University's Capacity for the Industry-Academia Collaboration on the Performance of Technology Commercialization. J. Artic. Manag. Syst. 2015, 26, 3. [CrossRef]

26. Kim, D.-J. Policy Effect Analysis of the Leaders in Industry-University Cooperation(LINC): Focused on Regional Impact of the LINC 2nd Step. Korean J. Policy Anal. Eval. 2018, 28, 27-47.

27. Kong, J.-H.; Lee, J.-H.; Heo, S.-Y.; Kim, K.; Eun, J.-H. Factors Affecting the Capabilities and Performance of Industry-Academic Cooperation: A Firm-Centered Approach. Econ. Geogr. Soc. Korea 2020, 23, 82-92.

28. Kim, K.H. The Impact of Institutional Environment and Strategic Resources on Technology Commercialization through Technology in University Technology Transfer Organizations and Companies; Sungkyunkwan University: Seoul, Korea, 2005.

29. Og, J.-Y.; Kim, B.-K. Technology transfer efficiency analysis of domestic public institutions. Technol. Innov. Res. 2009, 17, 131-158. 
30. Ryu, Y.; Kim, H.B.; Seo, E.J. In-Depth Evaluation of Projects to Support the Revitalization of Industry-Academic Cooperation System; KISTEP: Seoul, Korea, 2009.

31. Lee, S.C.; Bae, S.M.; Park, J.H. A study on Performance Oriented Industry-University Cooperation Convergence Program Model Based on Empirical Analysis of Satisfaction Evaluation for Family Companies. J. Digit. Converg. 2015, 13, 9-19.

32. Yun, J.J.; Jeong, E.; Yang, J. Open innovation of knowledge cities. J. Open Innov. Technol. Mark. Complex. 2015, 1, 16. [CrossRef]

33. Lee, S.; Lim, E.H.; Kim, H.K.; Kim, B.M.; Kim, C.H.; No, Y.H.; Lee, H.J. A Study on the Effectiveness of LINC(Leaders in INdustry-university Cooperation) Program. Korean J. Policy Anal. Eval. 2016, 12, 27-49. 